\title{
Cognitive Russian Modeling in the System of Corporate Governmance
}

\author{
Thibeault Irina V.
}

Prichina Olga S.

Gorelova Galina V.

\author{
Engineering Technology Academy, SFU, Taganrog, Russia \\ Email: thibeault.irina@gmail.com
}

Doi:10.5901/mjss.2015.v6n2p442

\begin{abstract}
The scientific article represents the Russian model qualitative specifics in the corporate governance based on the international trends in corporate reporting management solutions of "standardization" and "mathematization" of construction of fuzzy cognitive charts and cognitive modeling instruments. The main peculiarities of three qualitative "configurations" of agency problems related to corporate governance in the Russian companies and the specifics of information openness have been analyzed in the article, with the dissonance factors drawn out, thus allowing to systematize semi-structured factors into their relationship and interaction, which affect the quality of management in the Russian corporations and worldwide. Modern opportunities of realizing strategic business -planning modelling survey with the help of that cognitive method give the companies more flexible investment and business ogranization of researching target needs, opportunities effective management increasing, working out effective strategies and long-term plans of developing. All this contributes to the deterioration of the quality parameters of corporate governance.
\end{abstract}

Keywords: online-survey, modeling, fuzzy cognitive charts, corporate management, agency problem, corporate reporting;

\section{Introduction}

The Dynamically, changing global risk factors of the external business environment in conditions of "continuous" information disclosure impact national corporate governance models, determining the vibrant of internal and external management mechanisms, quality of corporate governance and informational transparency of the enterprises.

Worldwide trends in corporate governance associated with the strengthening of the role of different stakeholders, change not only the landscape of interactions the main participants of corporate relations - shareholders, board members, senior managers, but also affect the process of making and implementing the strategic activities of the company based on the variety of corporate risk management tools considering its impact on the environment and society as a whole. Corporate reporting system has been complicated due to increase of its volume, structural division, IT technology of submission and distribution, thus formalizing the transition to «ESG - framework» of corporate governance (environmental, social and corporate management) in order to facilitate the presentation of company stable development, not only in financial, but also non-financial, social, environmental and other aspects. Therefore, the focus is drawn on changing the target parameters and cognitive factors in the company development.

Global transition to integrated corporate reporting forms gives a powerful impact to the process of convergence of national corporate governance models as well as to the need to "fine tune" the internal and external corporate governance mechanisms system parameters.

Concurrently, the differences in implementation of corporate models at the national, regional and unit levels through the "network" of common factors of integrated corporate reporting are usually leveled. In turn, the semi-structured quality factors of corporate governance related to mental models of the organization of corporate accounting, and as a result - different levels of implementation of "agency problem" and opportunism top managers - require to use the cognitive modeling techniques in order to enable organization of knowledge about these factors in their relationship and interaction.

From this perspective, there is a need to consider the specifics of the Russian corporate governancemodel through the lens of cognitive tools based on the information development trends of corporate reporting. This article explores the aforesaid issues. 


\section{The Informative Corporate Reporting Trands}

This section looks at the various informative corporate reporting transa, a framework for categorizing the types of instruments used to assess cognitive modeling, as well as prior researches on international and Russian reporting trands.

\subsection{Definitions of informative reporting trands}

IT support of corporate activity is increasing annually, and according to the G3.1 requirements (sustainable development) and international standards of integrated corporate reporting the amount of reports have been increased significantly.

Ten years ago the annual report of a medium-sized company contained 70-80 pages. Today the annual report counts up to 400-500 pages of information, (Axelrod, R., 1976) which is read by about $1 \%$ of investors, and understood by no more than $0,05 \%$.

Enormous number of non-integrated corporate information loses its value both for the stakeholders, shareholders and managers. Basic characteristics of the integrated non-corporate reporting (Avdeev, S.V. and D.I. Makarenko, 2007) are listed below:

- A retrospective look at the company activity and development (the effect of "Rearview Mirror" in the car when it moves forward).

- Informational redundancy of quantitative and financial data ("overabundance" creates cognitive dissonance in such information processing).

- Lack of correlation between sections of the company corporate reporting in its financial, managerial, environmental and social aspects.

- Various degree of reliability and relevance of corporate reporting for the particular stakeholders of the company (absence of "segmentation" of corporate reporting for different groups of stakeholders: shareholders, prospective investors, regulatory authorities, members of the board of directors, etc.).

- Absence of integration of access channels for corporate reporting (for online internal management decisions, investor presentations and reports for regulatory bodies stakeholders and others);

- Lack of personalization and corporate information importance for the company, on the one hand and for its stakeholders-on the other hand;

- Delays in technology and development of non-integrated corporate reporting, low level of visualization, narrow level of access, etc.

The year 2013 was the most significant time for the creation of pre-conditions for the transition to the integrated corporate reporting forms, in which the coordinated actions of a number of international institutions (Figure 1) helped to create the system basics and (Avdasheva, S.B., Golikova V.V., Yakovlev A.A. and Sugiura F., 2007) the institutional environment for the integrated forms of corporate reporting in national corporate governance modeling.
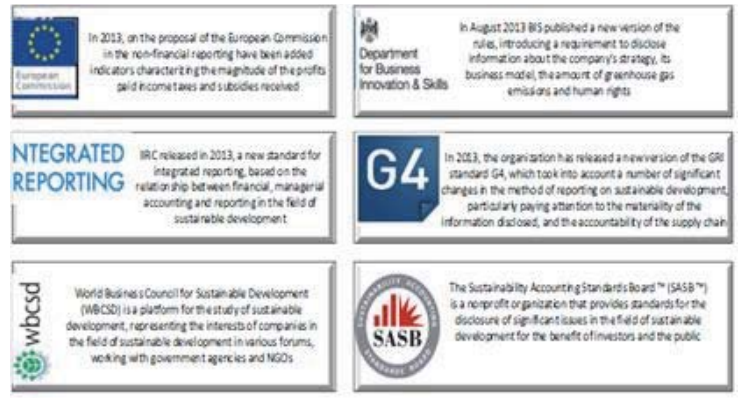

Figure 1. Conditions for introduction and use of integrated forms of corporate reporting in 2013

A new stage in the development of integrated forms of corporate reporting is characterized by motivation to balance the financial and managerial information that is shown in the following:

- Indicators reflecting the amount of profits paid for subsidies, income taxes, in the non-financial reporting have been added.

- Improving of reporting methodologies on the stationary development of the company, with particular emphasis on the materiality of corporate information and logistical coordination supply chains of goods. 
- Strengthening of the role of corporate responsibility in disclosing information about its strategic steps, business models, environmental and social impacts of economic activities, policies on human rights, etc.

- Optimization of financial and managerial information within the sustainability reports on the financial stability.

- Development of the integrated reporting forms in the NPO sector, formation of "common" internet sites for coordination of interests of NGOs, companies and their stakeholders in the field of their sustainable development.

At the same time, it should be noted that there is an uneven transition to the integrated forms of corporate reporting both within the external and national model of corporate management. For example, approximately $50 \%$ of corporations have joined into the integrated corporate.

reporting forms: 33\% in Russia, 9\% in Asia, 17\% in Africa's, 11\% in Australia, 17\% in South America, $6 \%$ in North (Dolgopyatova, T. 2014) and Central America. And this transformation is not straight-lined.

Such significant gap in the application of the integrated forms of corporate reporting in the regional "spectrum" can be explained by different levels of transaction expenses of the corporate relations participants within each national model. The lower transaction costs of interaction between the corporate relations participants are, the lower the percentage of the use of integrated forms of corporate reporting is.

However, with the growing number of companies that have transferred into the integrated corporate reporting forms in each country, the level of transaction costs for the "non-aligned" companies will be increasing, creating negative externalities outside, thus encouraging the companies to implementation of the integrated reporting forms.

Moreover, the spread of the integrated corporate reporting forms, particularly in the developing markets and the BRIC countries, facilitates the creation of the strategic platform for future competitive impacts of the investors from the developed countries.

To some extent, the global processes of standardization of accounting policies reflect the need of companies to create the "common" cognitive field of the companies' information exchange with the external business environment.

At the same time, there are certain objective limits for the effective implementation of standardization activities in the company which are conditioned by the following factors:

- Firstly, the economic life of each company is filled with many events, and managerial "record" of the economic facts, risk assessments, impact and implications for the future of competitive company's strategy, is the most important task of the integrated corporate reporting forms. But as for the "format" standards, application of similar techniques to the variety of events may lead to underestimation (or overestimation) of events risks, which is different for shareholders, potential investors and managers. It ultimately contributes to maladaptive evaluation of events and possibility to managerial manipulation in the justification of "new" factors of the company competitiveness with the long-term consequences for the particular stakeholders and shareholders (Gulakov, V.K., Camps, D.G. and Podvesovsky A.G., 2007).

- Secondly, various business processes have different costs of their "reflections" on the IFRS basis, so it is not uncommon that the costs for "translation" of business processes into the standards language may exceed the efficiency of their use(Erohin, D.V, Lagerev D.G, Laricheva E.A. and Podvesovsky A.G., 2006) (reporting for the sake of reporting.

- Thirdly, development of the unified accounting system of the company is based not only on the standards area, but also involves application of mathematical tools, which allows to overcome the "linguistic variation" of national accounting systems thus ensuring the achievement of a new level of reliability, availability, and integration of management information (KPMG Survey. "The future of corporate reporting: the pursuit of a common vision ", (2013) http://www.kpmg.com/RU/ru/lssuesAndlnsights/Articles Publications/Documents/ S_CG_6_rus.pdf).

- Fourthly, integration of corporate reporting framework requires its "specialization" and "segmentation" based on different objectives - strategic, tactical and operational management of economic risks, taking into account potential conflicts of interests within the corporate management - top managers, board members directors, shareholders and stakeholders of (Integrated Reporting Survey. "One step closer to integrated reporting", (2011) http://www.labrate.ru/discus/messages/20//R Discussion-Paper-2011_single-rus-40803.pdf);

- Fifthly, quality risk management of the company depends on the efficiency of application of different types: tangible and intangible company assets (financial, intellectual, industrial, organizational, management, online resources, etc.) that requires a wide range of mathematical techniques to support management decisions based on simulation modeling, business intelligence, expert evaluation, (PwC Global Survey "Putting a price on value" http://www.pwc.com/sustainability). 
Thus, in a global context, information corporate reporting trends stay on the "bracket" of two directions - the first is connected with the "standardization" trend of corporate reporting which is based on "prescription" standards of governance decisions, and, the second one is related to the opposite trend of "mathematization" of corporate reporting based on application of the mathematical tools, capable of overcoming the "linguistic" variability of national systems of corporate accounting and more adapted to the complexity of the administrative tasks of corporate governance.

Cognitive modeling methods can be actively used in the framework of "standardization" trends in corporate reporting to justify the long-term strategy of sustainable development of the companies and within the trend of "mathematization" support of corporate accounting solutions.

\section{Cognitive Modeling of Quality of the Russian Corporate Strateging Governamce Model}

This section looks at the cognitive modeling of quality of the Russian strategic governamce model, a framework for national traits used to assess the qulitive strategic management tools.

\subsection{National traits of the Russian corporate governance model}

In contrast to the Anglo-American model (model W - widely held corporation) and the German model (In -blockholder model) Russian model of corporate governance refers to the "mixed" type (PwC Global Survey "Business success beyond the short term: CEO perspectives on Sustainability" http://www.pwc.com/sustainability). Its characteristics are listed below:

- Availability of dense "core entrepreneurial", participants of corporate relations, (Kolvakh, O.I. and Kopytin V.Y., 2004) conditioned by the semi-structured solution of "agency problem".

- Significant direct and indirect influence of the state as a shareholder - (Kolvakh, O.I. and Kopytin V.Y., 2004) the companies in which a majority stake is owned by the government constitute $46 \%$.

- High equity concentration in the Russian companies -the average share value of the largest owner is 50-55\%, and (Kolvakh, O.I. and Kopytin V.Y., 2004) the second-largest shareholder is about $15 \%$.

- Structure of the board of directors in major Russian companies is formed by $44 \%$ of the shareholders or their representatives (Kolvakh, O.I. and Kopytin V.Y., 2004), while in the medium- and small-sized joint-stock companies (up to 50 employees) the board of directors may not exist at all, as the general director acts a a sole executive body.

- Low market maturity of external institutions of the national system of corporate governance - corporate gove rnance market, institution of independent directors, dysfunctional institution of bankruptcy, raiding, (Kolvakh, O.I. and Kopytin V.Y., 2004) etc.

- Conservatism of judicial practice of the Russian corporate law application, weak protection of minority shareholders' rights, etc.

These features of the Russian model affect the quality of corporate governance in the Russian companies. All of this is accentuated by the manifestations of corporate conflicts in the Russian companies, contributes to the protracted nature of their occurrence, and leads to a broader involvement in such conflicts of all participants of corporate relations from stakeholders to employees (Kolvakh, O.I., 2000), the most difficult process of their resolution and completion.

In order to change the qualitative parameters of corporate governance in the Russian economy a number of following factors have been identified:

- Firstly, there has been a downward trend in the level of concentration of share ownership in the Russian industrial sector.

- Secondly, a new draft National Corporate Governance Code (MCC) was adopted in February 2014 with the changes referring to (Isaev, D. 2010): responsibility of the board in risk governance, the Audit Committee chaired by the independent director, protection of shareholders dividend rights, payments of "golden parachutes" to managers in the amount not exceeding the reward for two years, ban to conceal the significant information from the members of the Board of Directors (Ershov, D.M. and Katchalov R.M., 2013).

- Thirdly, the progressive increase in the level of information transparency of the Russian companies (as estimated by Standard \& Poor's in 2011, the rating of information transparency of major Russian companies was-56, over $30 \%$ of the companies use forms of the integrated corporate reporting) (Mishurova, I.V. and Panfilov E.A. Corporate Governance M, 2010).

The Russian corporate governance model is characterized by semi-separation of management and ownership 
functions within the "agency problem" described in the works of Jensen and Murphy [Jehnsen, Murphy (National Report on Corporate Governance, 2013).

"Agency problem" is particularly acute for the Russian companies, and it is added by a few more quality contours. Three contours of agency problems of the Russian companies are reflected in the figure 2.

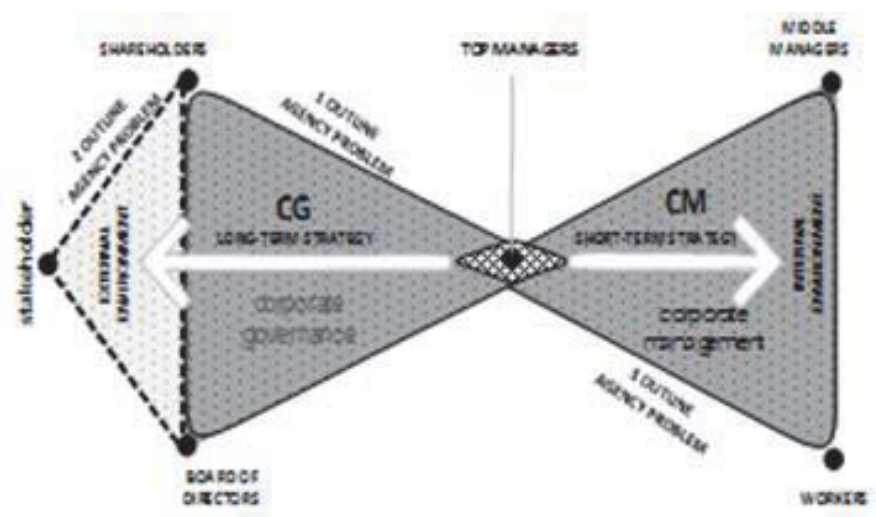

Figure 2. Three qualitative contours of agency problem in the Russian companies

Agency problem for the Russian companies has several implementation contours as follows:

- $\quad 1$ st contour line - by shareholders (principals)-top managers (agents),

- 2nd contour line - by shareholders (stakeholders),

- 3rd contour line - by shareholders - top managers (agents) - principle stuff.

Moreover, the Russian companies are characterized with the strong internal struggle for control over the resources of the enterprise between the various actors of corporate governance which is manifested in a high "price" for the company management and tough competition for corporate control, not only between the shareholders and top managers, but also between the different groups of shareholders and external stakeholders as well as workers, thus revealing high transaction costs of interaction between the participants of corporate governance and the impact on the quality parameters of the company's governance.

$33 \%$ of the Russian companies make reports in accordance with (G3.1) and 12\% of the companies in accordance with IFRS. (Mishurova, I.V. and Panfilov E.A., 2010) Most of the companies (86\%) present the dynamics of impact indicators within a few years, but only almost half of them (46\%) make comments on this dynamics. Target values for the reporting period (correlation of the plan and the fact) are even more rare (13\%) as well as the forecast values for the future periods -10\% (Figure 3). (Mishurova, I.V. and Panfilov E.A., 2010)

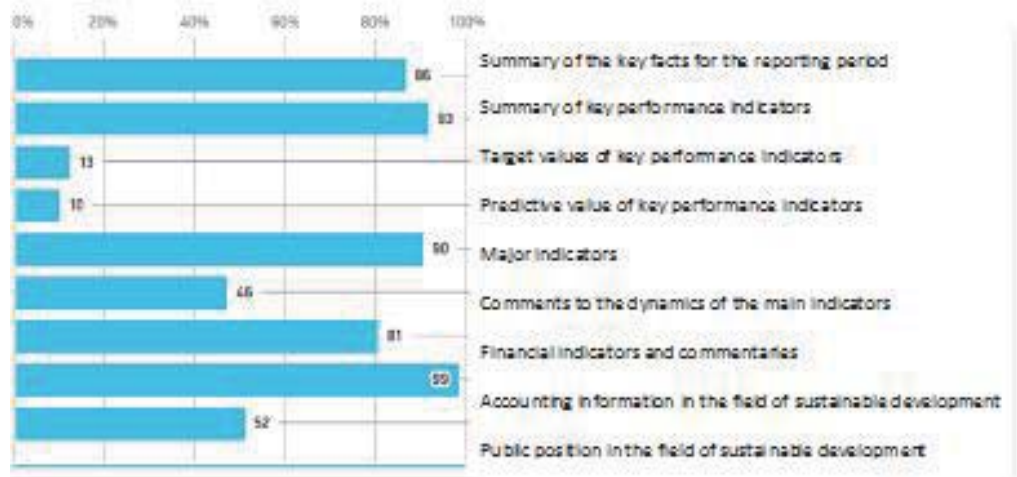

Figure 3. Corporate reporting the of Russian companies in 2013

Users' confidence to the accounting information contained in the reports is mostly based on the confirmation of the external independent party. There is no problem with reliable financial information, (the company complies with the law), while accuracy of the non-financial information (production, human, environmental and other data) may raise questions of the users, because only $20 \%$ of the companies make audit of their non-financial reporting due to insufficient level of disclosure of the company's stakeholders-Figure 4 (Mishurova, I.V. and Panfilov E.A., 2010). 


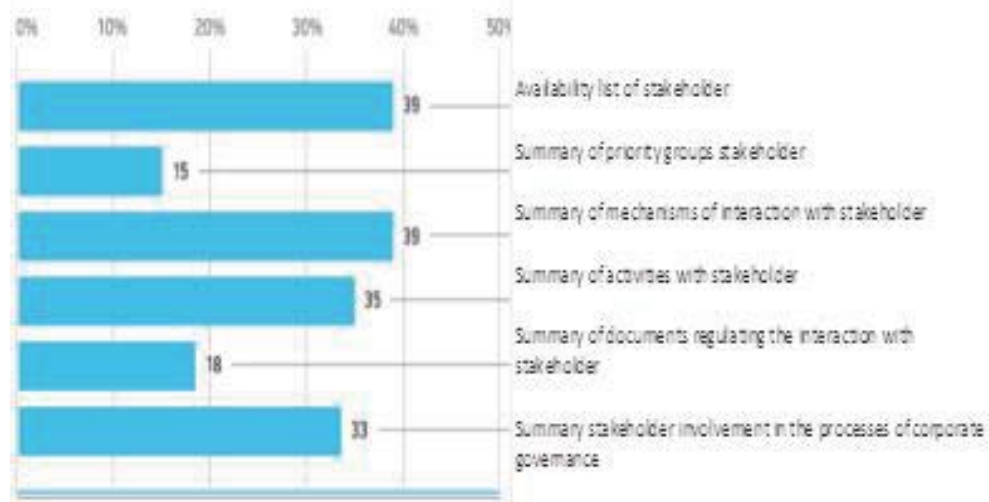

Figure 4. Information on the stakeholders of the Russian companies in 2013

Accounting information of low disclosure level in the Russian companies includes:

- Specific information about the business status and prospects of the companies supporting the implementation of the strategy (target and forecast figures, comments on the dynamics of indicators, etc.).

- Sustainability business information (business model, interaction with stakeholders, etc.).

- Synergies between company performance and remuneration of top governance.

Action mechanisms in domestic corporations are formed mainly under the influence of the Anglo-American model of corporate governance, focused on full informational transparency of the companies, dispersed equity, the developed market of corporate control, involvement of independent directors, preferential protection of minority shareholders' rights, etc.

At the same time, specifics of privatization mechanisms in Russia determined the insider nature of the corporate governance, which manifests itself in the high level of competition in the corporate control of the company between the shareholders, top managers and external stakeholders, insufficient development of the institution of independent directors and the corporate control market, dysfunctional institution of bankruptcy, etc.

Moreover, the qualitative parameters of "agency problem" generate high transaction costs of interaction between the participants of corporate relations and low quality of these relations in the Russian Federation. All this results in the growth of basic contradiction of the Russian model of corporate governance, which is expressed in the fact that application mechanisms of the Russian model are outsider, but on the other hand, the mechanisms of its implementation are insider, that is manifested in the absence of synchronization of internal and external corporate governance tools, conflict and corporate risk- relations in the Russian Federation.

\subsection{Instruments of cognitive modeling in corporate governance quality of Russian companies}

Cognitive modeling instruments which actively govern the study of semi-structured systems and processes was proposed by R. Axelrod (National Report on Corporate Governance, 2011). The term of "semi-structured" is understood as systems, parameters and laws which "behavior" is described mainly on a qualitative level, while changes in system parameters may lead to unpredictable changes in its structure (The draft of the new Corporate Governance Code February 13, 2014).

Cognitive research model of the semi-structured corporate governance problems are made based on the DSS "needle" software. This software applies methods of analytical processing, focused on the study of the system structure and receipt of forecast of its behavior under the different control actions purposed to synthesize effective governance strategies. [20]

Decision support system "NIDDLE" is a software product designed to analyze and simulate control strategies for complex, semi-structured systems which was developed by the scientific staff of the Department of "Informatics and Software" of Bryansk State Technical University under the direction of D.A. Korostelyova (Thibeault, Irina V., Prichina Olga S., Panfilova Elena A., Karanashev A. and Karasheva A., 2014).

The presented research problem of the quality of the Russian model of corporate governance (in terms of controllability, stability to perturbations, emergence, connectivity, sensitivity, etc.) is mainly reflected in the linguistic form and has a multi-factor structure. To generate a list of factors (concepts) the data from abstracts of scientists with a thesis on corporate governance in Russia in the period 2000-2013yrs was used. It allows to allocate 35 different factors 
affecting the corporate governance quality, namely:

1. System of value of the corporate governance participants

2. Low competitiveness of products

3. Lack of financial correlation and governance accounting system

4. Administrative governance methods

5. Lack of clear separation of monitoring functions and management of corporate ownership

6. Low level of labor productivity

7. Behavioral constraint of decision makers

8. Low inflow of foreign investments

9. Imbalance of innovation and investment activities

10. Low monitoring organization and control in the redistribution of company's resources

11. Low profitability of the enterprise

12. Low capitalization of the enterprise

13. Double subordination of business divisions

14. Low life level of the population

15. Concealing of material information

16. Low staff motivation

17. Inferior access of market participants to adequate information about the real economy of the enterprise

18. Weak interaction of the stock market and shareholders

19. High transaction expenses of interaction between corporate governance and participants

20. Low enforcement mechanisms of corporate governance

21. Low corporate culture

22. Crisis of fundamental corporate governance research

23. High corruption

24. Strong economic, organizational and legal constraints in the development of corporate governance models

25. Low disclosure transparency of governance information and low standards

26. Low economical growth

27. Inefficient mechanisms of corporate knowledge governance

28. The unbalanced corporate scorecard system

29. Ineffective quality governance system

30. Low flow of domestic investment in the corporate economy's sector

31. Low innovation capacity in production processes

32. Unbalanced system of economic relations

33. Low shares liquidity

34. Limited system of working capital governance

35. Low company reputation

36. In the process of data structuring the cause-and-effect relationships between them were determined along with the intensity of relationships between the concepts. Values of intensity of relationship between the concepts are reflected in Table.1

Table 1. The relationships intensity values between concepts

\begin{tabular}{|c|c|c|}
\hline \multicolumn{2}{|c|}{ Interpretation of the concept influence intensity } & The numerical variable value \\
\hline \multirow{2}{*}{ Minimum } & Strengthens & 0,$1 ; 0,2$ \\
\cline { 2 - 3 } & Weakens & $-0,1 ;-0,2$ \\
\hline \multirow{2}{*}{ Weak } & Strengthens & 0,$3 ; 0,4$ \\
\cline { 2 - 3 } & Weakens & $-0,3 ;-0,4$ \\
\hline \multirow{2}{*}{ Moderate } & Strengthens & 0,$5 ; 0,6$ \\
\cline { 2 - 3 } & Weakens & $-0,5 ;-0,6$ \\
\hline \multirow{2}{*}{ Strong } & Strengthens & 0,$7 ; 0,8$ \\
\cline { 2 - 3 } & Weakens & $-0,7 ;-0,8$ \\
\hline \multirow{2}{*}{ Maximum } & Strengthens & 0,$9 ; 1$ \\
\cline { 2 - 3 } & Weakens & $-0,9 ;-1$ \\
\hline \multicolumn{2}{|c|}{} & 0 \\
\hline
\end{tabular}


The purpose of constructing the map - is to determine the system-generating effect of factors and identify the relationship of factors that affects the quality of corporate governance. Fuzzy cognitive charts (Jensen, M. and K.J. Murphy., 1990) reflect the interconnection between the factors that differ in their intensity and may vary over time. Therefore, the intensity of the impact parameter has been introduced, and in contrast to the classical cognitive chart, its fuzzy modification reflects not only the direction of the relationship factors, but also the degree of intensity (weight) of influence between the concepts.

In other words, cognitive matrix is constructed on the basis of the sign and the weights of connections and is, actually, an adjacency matrix of the weighted digraph. Fuzzy cognitive chart of factors which affect the quality of corporate governance is presented at Figure 5.

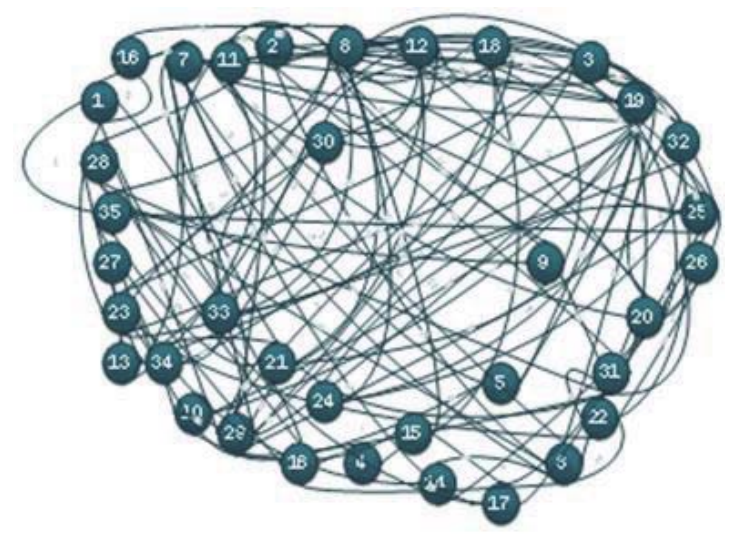

Figure 5. Fuzzy cognitive map of factors which affect the quality of corporate governance

The constructed cognitive map highlights the most important immediate links between the concepts that exist in the work of the Russian expert community. However, for a complete analysis of causal relationships quality control mechanism of corporate information is needed for the effects of mutual concepts dissonance and consonance. Analysis of the obtained values allows to conclude that the greatest negative impact on the system of corporate governance concepts have: (2) low competitiveness of the products - (3) absence of link between the financial correlation and management accounting system, (15) concealment of material information, (19) -high transaction costs of interaction between the participants of corporate governance, (20) - is low enforcement mechanisms of corporate governance. In turn, the greatest positive impact on the system of corporate governance has the concept (1) - system of values of the corporate governance participants.

The integral indicators of consonance and impact present the biggest interest for the analysis of the corporate governance quality. The following concepts are mainly impacted by the system: (8) - low inflow of foreign investment, (9) -imbalance of innovation and investment activities.

As in the case of such concepts as: (2) low competitiveness of the products, (3) lack of correlation of financial and management accounting system (15) concealment of material information, (19) high transaction costs of interaction between the participants of corporate governance (20) low enforcement mechanisms of corporate governance, the negative effect is bilateral, the negative cycles appear. This means that with the negative impact of these concepts their influence will be weakened, leading to the positive effect for the system of corporate governance in general. And with the positive impact on the concepts, their negative impact on the system of corporate governance will increase with the time.

Thus, the need for a positive impact on these concepts provides good opportunities and management actions to improve the quality of corporate governance. Investigation of the structure of corporate framework can be extended, if we consider the snapshot of the matrix system of indicators by highlighting its key points - the classes of concepts, which greatly affect the entire system of corporate governance.

The class of mutual positive influence at the snapshot level 0.9 contains 5 points (Figure 6), each of them producing the concepts which are possible and necessary to influence on in order to bring the quality system of corporate governance to the desired state. 


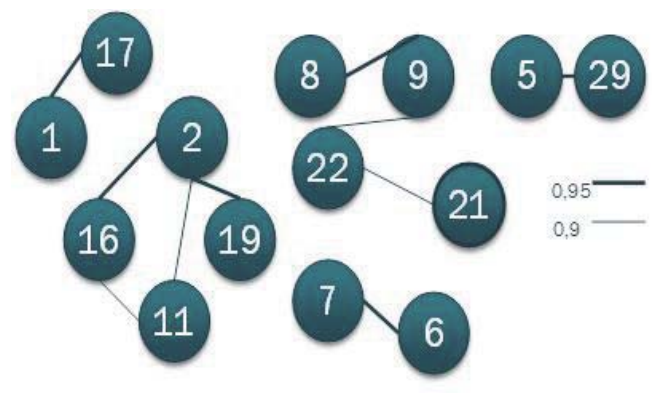

Figure 6. Mutual positive influence

In the first point $(2,16,19,11)$ it is necessary to draw attention on the concept of low goods competitiveness (2); in the second point $(8,9,22,21)$ the focus should be made on the point (9) of imbalance of innovation and investment activities. In the third $(1,17)$, forth $(6,7)$ and fifth $(5,29)$ points it is necessary to put attention on the following concepts: $(1)$ system of values of corporate governance participants (5) - clear separation between the unavailability control and monitoring functions of corporate ownership (6) - low level of labor productivity.

Bilateral negative impact on the quality system of corporate governance at the level 0,99 unites such concepts as: $1,13,26,19,35,10,6,5,14,15,7,29,33,32,18,29,11,21,2,23,9,8,27,4,16,25,30$ - Figure 7

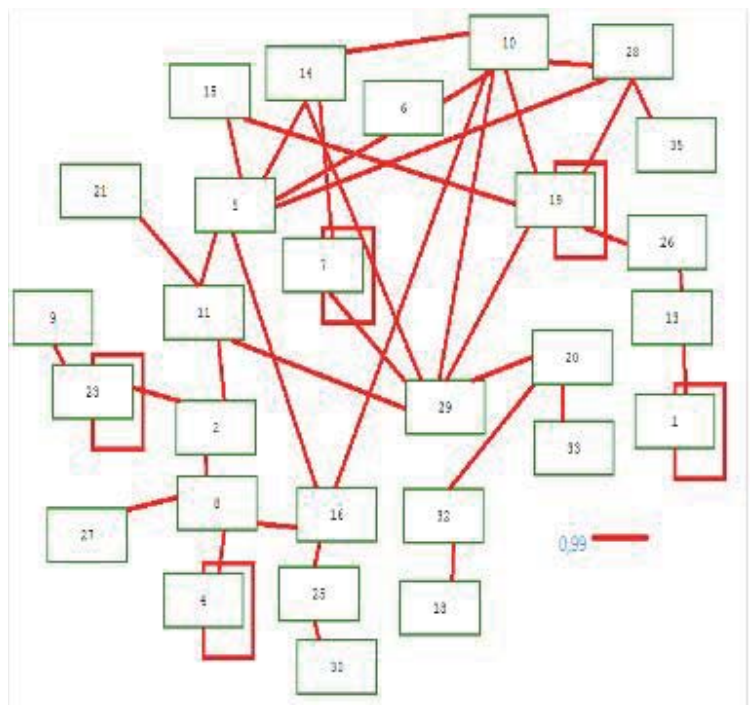

Figure 7. Mutual dissonance factors of corporate governance

It was found out that the concepts of: (6) -low level of productivity; (11) - low profitability, (22) -crisis of fundamental research on corporate governance are present simultaneously at the points of positive and negative interferences. This implies that the negative effects of managerial leadership on these factors requires great care, taking into account their specific actions within the system performance of fuzzy cognitive chart.

Analysis of indicators of cognitive charts in the quality system of corporate governance revealed both, the most cooperating and obstructing factors. The dominant factors of mutual dissonance (Figure 8) inlcude: (29) - the inefficient system of quality management; (19) -high transaction costs of interaction between the participants of corporate governance; (15) -concealment of material information; (5) -lack of clear separation of functions of control and management stock ownership; (14) - low standard of living; (10) - low organization of monitoring and control of the redistribution of company resources. 


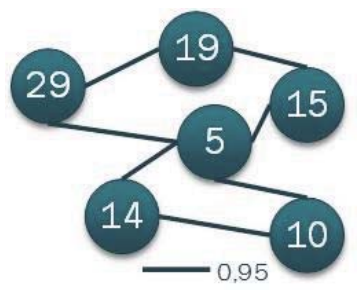

Figure 8. Alternate dissonance of negative influence factors on the system of corporate governance in the Russian companies

The inefficiency factor of quality management indicates the use of "formal" practice in the implementation of quality standards in the company corporate governance system. High transaction costs of interaction between the participants of corporate governance are largely associated with both the peculiarities of the Russian model of corporate governance, as well as with the effect of managerial body which organizes the interaction between the stakeholders, shareholders, company management and the Board of Directors. The factor of concealment of material information from the Board of Directors shows a significant level of opportunism of top managers and more favorable position in the competition for the internal control the company. To some extent, it is a lack of clear division between the labor control and management stock ownership. Concealment of material information for the Russian companies is mostly important with regards to the remuneration of top managers and board members affecting the low organization of monitoring and control in the redistribution of resources. All this contributes to the deterioration of the quality parameters of corporate governance.

\section{Findings and Discussion}

Methods of cognitive modelling can be widely applied within the trends of "standardization" of corporate governance in order to substantiate the long-term strategy of company sustainable development and "matematization" of managerial solutions for corporate governance.

Use of fuzzy cognitive cards in addition to the cognitive matrix adds to the visualization of the semi-structured factors, allowing to systematize them as principal, controllable, intermediate, cooperating and obstructing.

According to the Russian scientific community, among 35 factors which affect the quality of corporate governance, the following dominant factors of mutual dissonance can be determined based on the cognitive analysis results:

1) inefficient quality management system;

2) high transaction costs of interaction between the corporate governance participants;

3) concealment of material information; lack of clear separation between the functions of control and management of corporate ownership;

4) low life level of population;

5) low organization of monitoring and control of company resources distribution.

Instruments of cognitive modeling allow to monitor the quality of corporate governance based on the principles of consistency, authenticity, completeness and comparability of data in the linguistic form, thus providing for the quality of information and increasing the level of relevance, validity and integrity of managerial solutions in the sphere of semistructured factors of corporate governance.

\section{References}

Axelrod, R. (1976). The Structure of Decision: Cognitive Maps of Political Elites. - Princeton, NJ: Princeton University Press.

Avdeev, S.V. and D.I. Makarenko. (2007). Cognitive modeling for solving semistructured management systems (situations) // Managing large systems Issue. 16. М.: ИПУ RAS.

Avdasheva, S.B., Golikova V.V., Yakovlev A.A. and Sugiura F. (2007). External relationships of Russian corporations: [Pre-print]. Institute of Economic Research Discussion Paper Series. № 37. - 98 pp.

Dolgopyatova, T. (2014). Evolution of the structure and dynamics of concentration of ownership // In.: Essays on modernization of the Russian industry: the behavior of firms / Lea. Ed .: BV Kuznetsov. M. Publishing House HSE, p. 143-166.

Gulakov, V.K., Camps, D.G. and Podvesovsky A.G. (2007). DSS based on cognitive modeling "NEEDLE" // Software and Systems. № 3. pp. 12.

Erohin, D.V, Lagerev D.G, Laricheva E.A. and Podvesovsky A.G. (2006). Modelling innovative mechanism of the enterprise using fuzzy cognitive charts // Management in Russia and abroad. - № 3 
KPMG Survey. "The future of corporate reporting: the pursuit of a common vision ", (2013)

http://www.kpmg.com/RU/ru/IssuesAndlnsights/ArticlesPublications/Documents/S_CG_6_rus.pdf

Integrated Reporting Survey. "One step closer to integrated reporting", (2011) http://www.labrate.ru/discus/messages/20/IR DiscussionPaper-2011_single-rus-40803.pdf

9 PwC Global Survey "Putting a price on value" http://www.pwc.com/sustainability

10 PwC Global Survey "Business success beyond the short term: CEO perspectives on Sustainability" http://www.pwc.com/sustainability Sokolov, Y. (2010). Accounting as the sum of the facts of economic life M. Masters.

Kolvakh, O.I. and Kopytin V.Y. (2004) International Standards of Accounting and Reporting in the system of credit institutions: a mathematical justification and information technology software //Terra Economics. T. 2. № 1. pp. 85-96.

Kolvakh, O.I. (2000). Opportunistic accounting matrix (Models and conceptual solutions): Dr. of Science dissertation : 08.00 .12 : Moscow, 399p.

Isaev, D. (2010). Corporate Governance and Strategic Management: information aspect. M.

Ershov, D.M. and Katchalov R.M. Decision support systems in the procedures of formation of complex enterprise strategy / Preprint\# WP/2013/299. - M.: CEMI RAS, 2013. - 60 p.

Mishurova, I.V. and Panfilov E.A. (2010). Corporate Governance M .: Dashkov I.K., 2010. 527p.

National Report on Corporate Governance, Issue 6. M: 2013, pp. 320.

National Report on Corporate Governance, Issue№ 6. M: 2011, pp 320

The draft of the new Corporate Governance Code February 13, 2014.

A study of corporate transparency of Russian companies, (2013) http://transparency2013.downstream.ru/\#/ru

Thibeault, Irina V., Prichina Olga S., Panfilova Elena A., Karanashev A. and Karasheva A. (2014). Russian formula of corporate governance: cognitive modeling. World Applied Sciences Journal 32 (10): 2156-2166,ISSN 1818-4952 (c) IDOSI Publications, DOI: 10.5829/idosi.wasj.2014.32.10.1339

Jensen, M. and K.J. Murphy. (1990). CEO Incentives: It's Not How Much You Pay, But How. Harvard Business Review. 68(3), $138-153$.

SPPR "NEEDLE" http://iipo.tu-bryansk.ru/quill/download.html 